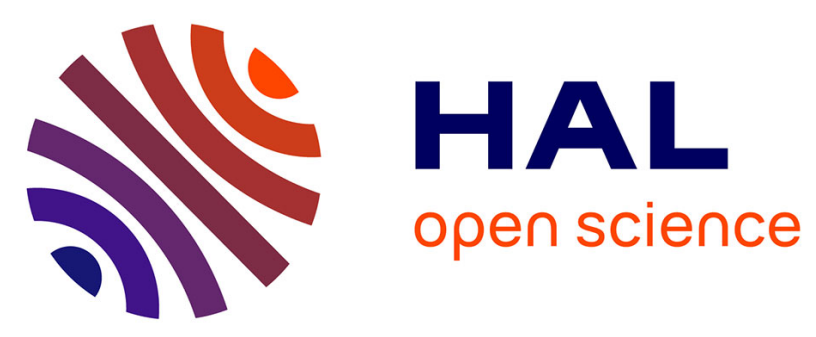

\title{
First evidences that the ectomycorrhizal fungus Paxillus involutus mobilizes nitrogen and carbon from saprotrophic fungus necromass
}

Emila Akroume, François Maillard, Cyrille Bach, Christian Hossann, Claude Brechet, Nicolas Angeli, Bernhard Zeller, Laurent Saint-André, Marc Buee

\section{To cite this version:}

Emila Akroume, François Maillard, Cyrille Bach, Christian Hossann, Claude Brechet, et al.. First evidences that the ectomycorrhizal fungus Paxillus involutus mobilizes nitrogen and carbon from saprotrophic fungus necromass. Environmental Microbiology, 2019, 21 (1), pp.197-208. 10.1111/14622920.14440 . hal-02154447

\section{HAL Id: hal-02154447 https://hal.science/hal-02154447}

Submitted on 12 Jun 2019

HAL is a multi-disciplinary open access archive for the deposit and dissemination of scientific research documents, whether they are published or not. The documents may come from teaching and research institutions in France or abroad, or from public or private research centers.
L'archive ouverte pluridisciplinaire HAL, est destinée au dépôt et à la diffusion de documents scientifiques de niveau recherche, publiés ou non, émanant des établissements d'enseignement et de recherche français ou étrangers, des laboratoires publics ou privés. 


\section{First evidences that the ectomycorrhizal fungus Paxillus involutus mobilizes nitrogen and carbon from saprotrophic fungus necromass}

\author{
Emila Akroume, ${ }^{1,2,3,4 \dagger}$ François Maillard, ${ }^{1,2 \dagger}$ \\ Cyrille Bach, ${ }^{1,2}$ Christian Hossann, ${ }^{5}$ Claude Brechet, ${ }^{5}$ \\ Nicolas Angeli, ${ }^{5}$ Bernhard Zeller, ${ }^{3}$ \\ Laurent Saint-André ${ }^{3}$ and Marc Buée ${ }^{10}{ }^{1,2 *}$ \\ ${ }^{1}$ INRA, UMR1136 Interactions Arbres-Microorganismes, \\ F-54280, Champenoux, France. \\ ${ }^{2}$ Université de Lorraine, UMR1136 Interactions Arbres- \\ Microorganismes, F-54500, Vandœuvre-lès-Nancy, \\ France. \\ ${ }^{3}$ INRA UR 1138 Biogéochimie des Ecosystèmes \\ Forestiers, Centre INRA de Nancy, Champenoux, \\ France. \\ ${ }^{4}$ Agroparistech, Centre de Nancy, F-54000, Nancy, \\ France. \\ 5INRA UMR1137 Ecologie et Ecophysiologie Forestière, \\ Centre INRA de Nancy, Champenoux, France.
}

\section{Summary}

Fungal succession in rotting wood shows a surprising abundance of ectomycorrhizal (EM) fungi during the late decomposition stages. To better understand the links between EM fungi and saprotrophic fungi, we investigated the potential capacities of the EM fungus Paxillus involutus to mobilize nutrients from necromass of Postia placenta, a wood rot fungus, and to transfer these elements to its host tree. In this aim, we used pure cultures of $P$. involutus in the presence of labelled Postia necromass $\left({ }^{15} \mathrm{~N} /{ }^{13} \mathrm{C}\right)$ as nutrient source, and a monoxenic mycorrhized pine experiment composed of labelled Postia necromass and $P$. involutus culture in interaction with pine seedlings. The isotopic labelling was measured in both experiments. In pure culture, $P$. involutus was able to mobilize $\mathrm{N}$, but $\mathrm{C}$ as well, from the Postia necromass. In the symbiotic interaction experiment, we measured high ${ }^{15} \mathrm{~N}$ enrichments in all plant and fungal compartments. Interestingly, ${ }^{13} \mathrm{C}$ remains mainly in the

Received 17 January, 2018; accepted 5 October, 2018. *For correspondence. E-mail marc.buee @ inra.fr. Tel : +33 (0)3 83394072 ; Fax: +33 (0)3 83394069 . "These authors contributed equally to this work. mycelium and mycorrhizas, demonstrating that the EM fungus transferred essentially $\mathrm{N}$ from the necromass to the tree. These observations reveal that fungal organic matter could represent a significant $\mathrm{N}$ source for EM fungi and trees, but also a $\mathrm{C}$ source for mycorrhizal fungi, including in symbiotic lifestyle.

\section{Introduction}

In forest ecosystems, dead wood and soil organic matter (SOM) represent essential habitats for a wide variety of organisms (Kruys and Jonsson, 1999; Nordén et al., 2004) and consequently an energy resource for microbes and associated ecosystem services, such as soil carbon sequestration (Clemmensen et al., 2013). Interestingly, if soil microorganisms are highly involved in organic matter decomposition and cycling, their own cell degradation and their residual products are important components of this SOM (Schmidt et al., 2011). Indeed, plant tissues, soil fauna and microorganisms are the primary sources of soil organic carbon in forest soils (Six et al., 2006).

In these ecosystems, saproxylic fungi are highly relevant in the process of the degradation of dead wood to mobilize carbon (Blanchette, 1995; Rajala et al., 2015) and recycle the other major nutrients, such as nitrogen and phosphorus (Watkinson et al., 2006). In addition, this decomposition of woody debris is a temporally dynamic process supported by the succession of different fungal ecological groups (Stockland et al., 2012). Interestingly, diverse studies reported the recurrent presence and potential role of ectomycorrhizal (EM) fungi in this decaying process or in the saproxylic food web dynamics (Tedersoo et al., 2003; Buée et al., 2007; Rajala et al., 2012, 2015; Walker et al., 2012). EM fungi are well known to provide soil-derived nutrients in exchange for carbohydrates produced by photosynthesis from the host tree. This exchange of commodities between two interacting partners is the most basic element of any biological market (Werner et al., 2014). In the EM symbiosis, this market involves the exchange of different commodities by both partners. Indeed, EM fungi are highly efficient at exploring the soil and mobilizing nutrients, particularly 
organic ones that would not be directly available to their plant hosts (Smith and Read, 2010). Therefore, rotting wood could constitute a particular niche for EM fungi involved in a symbiotic interaction with their host-tree roots. More precisely, it was suggested that certain EM fungi colonized dead wood acting as scavengers by degrading wood rot fungi (Buée et al., 2007; Rajala et al., 2012; Mäkipää et al., 2017; Maillard et al., 2018). The abilities of EM fungi to mobilize nutrients from dead organic matter have been suggested in numerous studies (Buée et al., 2005; Courty et al., 2007; Lindahl and Finlay, 2006; Talbot et al., 2013; Vaario et al., 2002). Some authors have even reported that EM fungi would be able to mobilize carbon from plant organic matter (e.g., cellulose and hemicellulose) for their development (Durall et al., 1994); but also, under certain conditions, to mitigate or offset losses in the host-tree carbon budget through a mixotrophic interaction (Cullings and Courty, 2009; Bréda et al., 2013). Rineau et al. (2012) have investigated the mechanisms by which Paxillus involutus could degrade organic matter. The expression profile of genes potentially involved in organic matter degradation revealed that only few of them were expected to be involved in plant cell wall degradation. Additionally, Rineau et al. (2012) reported in this study that $P$. involutus induces chemical changes in plant organic matter similar to hydroxyl radical attacks of brown-rot fungi, involving Fenton chemistry. More recently Kohler et al. (2015) demonstrated strong losses of genes encoding enzymes involved in the decay of lignin within EM fungal genomes, including class II peroxidases or glyoxal oxidases, suggesting they have limited genomic capacity to degrade lignocellulose. Nevertheless, a limited presence of class II peroxidases and glyoxal oxidases is not an evidence for a limited capacity to degrade plant cell walls. Indeed, despite observed expansions in peroxidase gene families within white rot fungi, Talbot et al. (2015) did not find that class II peroxidase gene copy number predicted peroxidase activity well within this fungal guild. Finally, through different strategies, EM fungi could improve organic matter decomposition and cometabolic degradation of recalcitrant organic complexes, thereby releasing the organic $\mathrm{N}$ necessary to their hosts (Lindahl and Tunlid, 2015).

While numerous studies have focused their attention on plant organic matter and deciphered microbial lignocelluloIytic functions, other articles focused on the decomposition of microbial organic matter. In particular, fungal residues provide polymeric substances, such as chitin, glucans, lipids, melanin and a wide range of proteins, corresponding to diverse sources of nutrients in soils (Bartnicki-Garcia, 1968; Kögel-Knabner, 2002; Godbold et al., 2006; Lorenz et al., 2007; Nannipieri and Eldor, 2009). As an example, soil chitin is derived mainly from fungal and arthropod necromass, and even if chitin is the most abundant aminopolysaccharide in nature (Kumar, 2000), little is known about the turn-over of this large pool of organic nitrogen. Different authors have suggested that EM fungi are capable of degrading fungal necromass and to lyse associated cell walls. Indeed, Leake and Read (1990) have reported potential chitinolytic activities from EM fungi by quantifying the mycelial growth of diverse ericoid and EM fungi with chitin as the sole source of nitrogen. Complementary to these observations, enzymatic approaches confirmed the expression of proteolytic and chitinolytic activities from EM fungal mycelium in presence of saprotrophic fungal necromass, or pure chitin (Hodge et al., 1995; Mucha et al., 2006; Mucha et al., 2007; Maillard et al., 2018). Moreover, Lindahl and Taylor (2004) reported the frequent occurrence of $\mathrm{N}$-acetylhexosaminidase-encoding genes in ectomycorrhizal fungi. Finally, although some studies have shown EM chitinase or proteolytic activities in the presence of fungal necromass, there has been no effective demonstration of nitrogen and carbon mobilization from fungal cell walls to the EM fungus, with a potential transfer to the plant host.

The use of biomarkers in combination with stable isotope analysis is an efficient approach in microbial ecology to study carbon or nitrogen transfer. Coupled with analytical techniques, such as gas chromatography-combustionisotope ratio mass spectrometry, stable isotope labelling (e.g., for ${ }^{15} \mathrm{~N}$ uptake or ${ }^{13} \mathrm{C}$ mobilization or respiration) provides the unique opportunity to link biological identity (biomarker) and biopolymer decomposition and associated activities (Boschker and Middelburg, 2002). Using ${ }^{13} \mathrm{C} /{ }^{15} \mathrm{~N}$ stable isotopic tracing, the aims of our study were (i) to prove the capability of an EM fungus to decompose the necromass of a ligninolytic fungus and mobilize nutrients ( $\mathrm{N}$ and/or $\mathrm{C}$ ) in a pure culture experiment; (ii) to extend this demonstration to symbiotic conditions; (iii) to quantify $\mathrm{N}$, and potentially $\mathrm{C}$, transfers from the fungal necromass to the EM fungus and its host-plant in a symbiotic lifestyle and (iv) to propose an allocation model of $\mathrm{C}$ and $\mathrm{N}$ in this symbiotic association connected to fungal necromass, as major nutrient resource. Finally, this study could provide founding results to prove the role of EM fungi in the decomposition of microbial necromass and to better understand the $\mathrm{C}$ and $\mathrm{N}$ elemental cycles closing in forest ecosystems. For these aims, we traced the flow of labelled fungal necromass in two controlled systems: pure culture of the EM fungus $P$. involutus and tree seedlings inoculated with this fungus in monoxenic conditions.

\section{Results \\ ${ }^{13} \mathrm{C} /{ }^{15} \mathrm{~N}$ isotopic and enzymatic activity measurements in EM pure culture experiment}

First, we measured the direct incorporation of ${ }^{15} \mathrm{~N}$ and ${ }^{13} \mathrm{C}$ in $P$. involutus mycelium growing in the presence of 
$P$. placenta labelled necromass. The isotope analyses were also conducted on dead mycelium of $P$. involutus to quantify adsorbed ${ }^{13} \mathrm{C}$ and ${ }^{15} \mathrm{~N}$ label to mycelium after washing. Thus, the transfers of ${ }^{13} \mathrm{C}$ and ${ }^{15} \mathrm{~N}$ isotopes were assessed by calculating both enrichments within alive and freeze-dried $P$. involutus mycelium (Table 1). After 20 days of growth as pure cultures at $20^{\circ} \mathrm{C}$ in the dark, we measured significant ${ }^{13} \mathrm{C}$ and ${ }^{15} \mathrm{~N}$ enrichment in $P$. involutus mycelium growing in the presence of labelled necromass in comparison with the control and unlabelled treatments $(p$-value $<0.001)$. The $\delta^{13} \mathrm{C}$ have shifted from $-12.68 \%$ o $(\mathrm{SD} \pm 0.2)$ in unlabelled necromass conditions to $123.50 \%$ o $( \pm 33.6)$ in labelled necromass conditions, and $\delta^{15} \mathrm{~N}$ have shifted from $8.77 \%$ o $( \pm 3.9)$ in unlabelled necromass conditions to $947.66 \%( \pm 91.2)$ in labelled necromass conditions. Freeze-dried $P$. involutus mycelium (patches) was slightly enriched in the presence of labelled necromass (adsorbed material). But this residual labelling remained very low, approximately $3 \%$ of the ${ }^{13} \mathrm{C}$ and ${ }^{15} \mathrm{~N}$ living $P$. involutus labelling.

From the same pure-culture experiments, soluble protein contents of washed $P$. placenta necromass were quantified as relatively low (1.2\% of dry mass). Moreover, $P$. placenta necromass was hydrolyzed also to determine chitin content. Because we found that chitin represented $15.3 \%$ of $P$. placenta dry mass (details in Experimental Procedures), we measured the $\mathrm{N}$-acetylglucosaminidase (NAGase) activity of $P$. involutus in presence of this necromass. The NAGases measured in the culture medium of $P$. involutus were significantly higher ( $p$-value $<0.05$ ) in the presence of unlabelled or labelled saprotrophic fungal necromass than in the control treatments, without necromass (Supporting Information Fig. S1). Indeed, the constitutive NAGase activity of $P$. involutus was close to $400 \mathrm{pmol} \mathrm{ml}^{-1} \mathrm{~min}^{-1}$ in the absence of necromass. This enzymatic activity was increased by $50 \%$ in the presence of $P$. placenta necromass. These increases were similar with unlabelled and labelled necromass. We did not detect $\mathrm{N}$-acetylglucosaminidase activity from solution containing only the $P$. placenta necromass, confirming that the extracellular enzymatic activity measured in our experiments was exclusively due to $P$. involutus.

\section{${ }^{13} \mathrm{C} /{ }^{15} \mathrm{~N}$ isotopic results for the ectomycorrhized pine seedlings experiment}

In a second experiment, we measured the transfer of labelled elements in an experimental device consisting of $P$. involutus and Scots pine (Pinus sylvestris) in presence of labelled, or unlabelled, necromass. The ${ }^{13} \mathrm{C}$ and ${ }^{15} \mathrm{~N}$ labelling was assessed by calculating $\delta^{13} \mathrm{C}$ and $\delta^{15} \mathrm{~N}$ for each biological compartment of symbiotic partners: EM mycelium, EM root tip, stem and needle (Table 2). Furthermore, we separated necromass plugs from the perlite/mycelium mixture for residual labelling measurements at the end of the experiment. Indeed, $\delta^{13} \mathrm{C}$ and $\delta^{15} \mathrm{~N}$ were quantified from agar patches containing the ligninolytic fungal necromass before and after consumption by the ectomycorrhizal fungus. On the other hand, since it was technically difficult to separate the $P$. involutus extraradical mycelium from the perlite substrate, they were considered to be a single compartment. The differences of $\delta^{13} \mathrm{C}$ and $\delta^{15} \mathrm{~N}$ between natural abundance and labelled conditions were significant for all compartments. Moreover, as a control, we quantified $\mathrm{C}$ and $\mathrm{N}$ from pure sterile perlite using a continuous flow $\mathrm{CN}$ analyzer (Carlo Erba NA1500, Milano, Italy). We measured negligible quantities of $\mathrm{C}$ and $\mathrm{N}(0.03 \%$ and $0.006 \%$ respectively), confirming that the $\mathrm{C}$ and $\mathrm{N}$ measured in the mycelium/perlite compartment belonged only to the fungal material and/or root exudates.

In comparison to the control, the ${ }^{15} \mathrm{~N}$ enrichment was highly significant for all tree compartments and for the EM mycelium colonizing the perlite. The mycorrhized roots were the most enriched compartments. In addition, the mycorrhized roots and the ectomycorrhizal mycelium were highly enriched in ${ }^{13} \mathrm{C}$ (Table 2), but the $\delta^{13} \mathrm{C}$ decreased progressively from the EM fungal mycelium to the stem, with a relatively low labelling in the needles. Indeed, in the plant aboveground compartments, the

Table 1. Average values of $\delta^{13} \mathrm{C}$ and $\delta^{15} \mathrm{~N}$ for living $(n=6)$ or freeze-dried $(n=4)$ Paxillus involutus mycelium in pure culture experiment in the absence or presence of labelled and unlabelled saprotrophic fungal necromass.

\begin{tabular}{|c|c|c|c|c|c|c|}
\hline & \multicolumn{2}{|l|}{ No necromass } & \multicolumn{2}{|c|}{ Unlabelled necromass } & \multicolumn{2}{|l|}{ Labelled necromass } \\
\hline & $\delta^{13} \mathrm{C}(\% \circ)$ & $\delta^{15} \mathrm{~N}(\% \circ)$ & $\overline{\delta{ }^{13} \mathrm{C}(\% \circ)}$ & $\delta{ }^{15} \mathrm{~N}(\%)$ & $\overline{\delta{ }^{13} \mathrm{C}(\%)}$ & $\delta{ }^{15} \mathrm{~N}(\%)$ \\
\hline EM mycelium & $-13.41(0.5) \mathrm{b} \mathrm{ns}$ & $7.34(2.0) \mathrm{c} \mathrm{ns}$ & $-12.68(0.2) \mathrm{b} n \mathrm{~ns}$ & $8.77(3.9) b^{\star *}$ & $123.50(33.6) a^{\star \star \star}$ & $947.66(91.2) a^{* * *}$ \\
\hline $\begin{array}{l}\text { Freeze-dried EM } \\
\text { mycelium }\end{array}$ & $-12.21(0.1) b$ & $3.28(0.6) \mathrm{b}$ & $-12.38(0.1) c$ & $2.62(0.5) c$ & $-3.65(1.1) \mathrm{a}$ & $29.49(5.7) \mathrm{a}$ \\
\hline
\end{tabular}

The freeze-dried $P$. involutus mycelium condition allows controlling potential ${ }^{15} \mathrm{~N}$ or ${ }^{13} \mathrm{C}$ labelling contamination resulting from passive adsorption from the labelled material. The values in the brackets correspond to the standard deviation. Differences in $\delta^{13} \mathrm{C}$ and $\delta^{15} \mathrm{~N}$ signatures were statistically analyzed using Kruskal-Wallis test by ranks (the different letters indicate a significant difference with $p$-value $<0.05$ ) for necromass type treatments and Wilcoxon signed-rank test ( $p$-value $<0.05^{*}, p$-value $<0.01^{* *}, p$-value $<0.001^{* * *}$ ) for $P$. involutus mycelium type treatments. 
Table 2. Average values of $\delta^{13} \mathrm{C}$ and $\delta^{15} \mathrm{~N}$ for monoxenic $P$. involutus / Pinus experiment.

\begin{tabular}{|c|c|c|c|c|}
\hline & \multicolumn{2}{|c|}{ Unlabelled necromass ( $P$. placenta) } & \multicolumn{2}{|c|}{ Labelled necromass (P. placenta) } \\
\hline & $\delta{ }^{13} \mathrm{C}(\% \circ)$ & $\delta{ }^{15} \mathrm{~N}(\%)$ & $\delta{ }^{13} \mathrm{C}(\%)$ & $\delta{ }^{15} \mathrm{~N}(\%)$ \\
\hline Patch (before the experiment) & $-17.34(0.12) b$ & $7.93(0.27) a$ & $434.34(19.14) a^{*}$ & $5074.52(34) a^{*}$ \\
\hline Patch (end of the experiment) & $-16.79(0.02) a b$ & $4.31(1.26) \mathrm{bc}$ & $289.21(46.72)$ ab ns & $3162.41(579.5)$ a ns \\
\hline Perlite + EM mycelium & $-12.31(0.6) \mathrm{a}$ & $2.29(0.3) \mathrm{d}$ & $2.12(7.1) b^{* *}$ & $79.37(39.7) \mathrm{c}^{\star *}$ \\
\hline Mycorrhized roots & $-22.71(1.4) \mathrm{c}$ & $4.60(0.8) \mathrm{b}$ & $-9.52(4.3) c^{* * *}$ & $341.67(47.7) b^{* \star *}$ \\
\hline Stem & $-24.33(1.8) d$ & $2.09(0.4) d$ & $-19.85(1.6) d^{* *}$ & $310.68(60.4) b$ ** \\
\hline Needle & $-24.26(1.3) d$ & $3.63(0.9) \mathrm{c}$ & $-17.20(3.6) d^{* \star}$ & $311.39(122.1) b$ ** \\
\hline
\end{tabular}

Values were obtained from all biological compartments studied (mycelium/perlite, EM roots, stem and needles) and from 'necromass plugs' in enriched $(n=5)$ and natural abundance $(n=5)$ conditions. The values in the brackets correspond to the standard deviation. Differences in $\delta^{13} \mathrm{C}$ and $\delta^{15} \mathrm{~N}$ signatures were statistically analyzed using Kruskal-Wallis test by ranks (the different letters indicate a significant difference with $p$-value $<0.05)$ for compartment treatments and Wilcoxon signed-rank test ( $p$-value $<0.05{ }^{*}, p$-value $<0.01^{* *}, p$-value $\left.<0.001{ }^{* * *}\right)$ for necromass type treatments.

$\delta^{13} \mathrm{C}$ in the needles changed from $-24.26 \%$ 。 $( \pm 1.3)$ for the control to $-17.2 \%$ o $( \pm 3.6)$ for the labelled treatment, and, in the belowground area, the $\delta^{13} \mathrm{C}$ shift from $-12.3 \%$ o $( \pm 0.6)$ to $+2.1 \%$ o $( \pm 7.1)$ in the EM mycelium/perlite compartment.

With the goal to demonstrate the absence of ${ }^{13} \mathrm{C}$ enrichment in the plants by gas exchanges, resulting from EM fungal respiration, two Magenta boxes were connected with a gas-tight flexible tube (Supporting Information Fig. S2). In this experiment, in the nonmycorrhizal control plants were not enriched in ${ }^{15} \mathrm{~N}$ and ${ }^{13} \mathrm{C}$ by the neighbouring mycorrhizal plant in the presence of labelled necromass. Indeed, the needle labelling in the non-mycorrhizal control plants was not significantly different to the needle labelling of control plants growing with unlabelled necromass (Fig. 1): $\delta^{13} \mathrm{C}=-27.65 \%$ \% $( \pm 1.01)$ and $\delta^{15} \mathrm{~N}=-7.99 \%$ \% $( \pm 1.4)$. These results confirmed the absence of ${ }^{13} \mathrm{CO}_{2}$ atmospheric transfer.

\section{Allocation model of the enrichment by biological compartment in the symbiotic association}

The quantities $(\mathrm{mg})$ of ${ }^{15} \mathrm{~N}$ and ${ }^{13} \mathrm{C}$ were calculated from each compartment for each tree from the compartment biomass and the value measured in ${ }^{13} \mathrm{C} /{ }^{15} \mathrm{~N}$ atomic percent. Nevertheless, it was not possible to separate the $P$. involutus mycelium from perlite, and therefore to quantify the biomass corresponding to this extramatricial mycelium. In this case only, we used $\delta \%$ values because the very low biomass of $P$. involutus was negligible compared with the pine biomass: roots, stems and needles. The quantities of carbon and nitrogen by compartment were compared between the two treatments: labelled and unlabelled necromass patches. The proportions of ${ }^{15} \mathrm{~N}$ and ${ }^{13} \mathrm{C}$ and their distribution in the different biological compartments were estimated from the labelled fraction that had been mobilized from the necromass patches in comparison to initial labelling, as illustrated in Fig. 2. About $10.9 \%$ of ${ }^{13} \mathrm{C}$ and $52.5 \%$ of ${ }^{15} \mathrm{~N}$ was mobilized

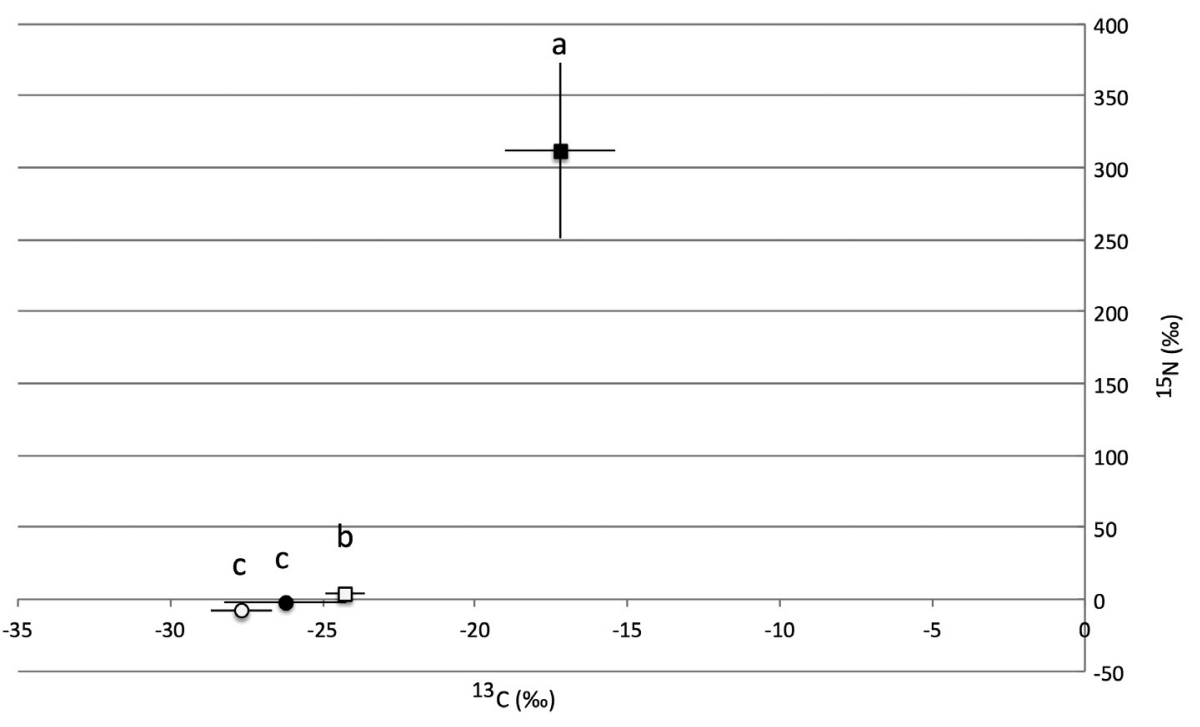

Fig. 1. Measurements of ${ }^{15} \mathrm{~N}$ and ${ }^{13} \mathrm{C}$ (expressed as $\delta^{13} \mathrm{C} \%$ or $\delta^{15} \mathrm{~N} \%$ ) transfers in pine needles, in presence of labelled or unlabelled $P$. placenta necromass. Black square: mycorrhized pines with labelled necromass $(n=5)$; white square: mycorrhized pines with unlabelled necromass $(n=5)$; black circle: control\#1 (nonmycorrhized pines with labelled necromass; $n=2$ ); white circle: control\#2 (non-mycorrhized pines for ${ }^{13} \mathrm{CO}_{2}$ trapping - experimental device is illustrated in Supporting Information Fig. S2; $n=2$ ). See all details in Experimental Procedures section. Differences in $\delta^{13} \mathrm{C}$ and $\delta^{15} \mathrm{~N}$ signatures were statistically analyzed using Kruskal-Wallis test by ranks (the different letters indicate a significant difference with $p$-value $<0.05$ ). 
Fig. 2. Repartition model of the initial ${ }^{15} \mathrm{~N}$ (a) and ${ }^{13} \mathrm{C}$ (b) within the different compartments of the tree - EM fungus symbiotic interaction from the inoculum patches of freeze-dried $P$. placenta $(n=5)$. At the end of the experiment, the labelled patches were carefully separated from the other underground compartments (EM roots and perlite - EM mycelium). The compartment 'Perlite-EM mycelium' corresponds to the non-plant material present in the plastic Magenta boxes. The 'mycorrhized roots' compartment consisted of the entire root system. The allocation percentages were computed as atom percentage ${ }^{13} \mathrm{C}$ and ${ }^{15} \mathrm{~N}$ and weighted by biomass of biological material in each compartment. Relative abundance ( $\delta \%$.) values were used for EM mycelium only, because the mycelium biomass could not be quantified and it was negligible compared with plant biomass. [Color figure can be viewed at wileyonlinelibrary.com]
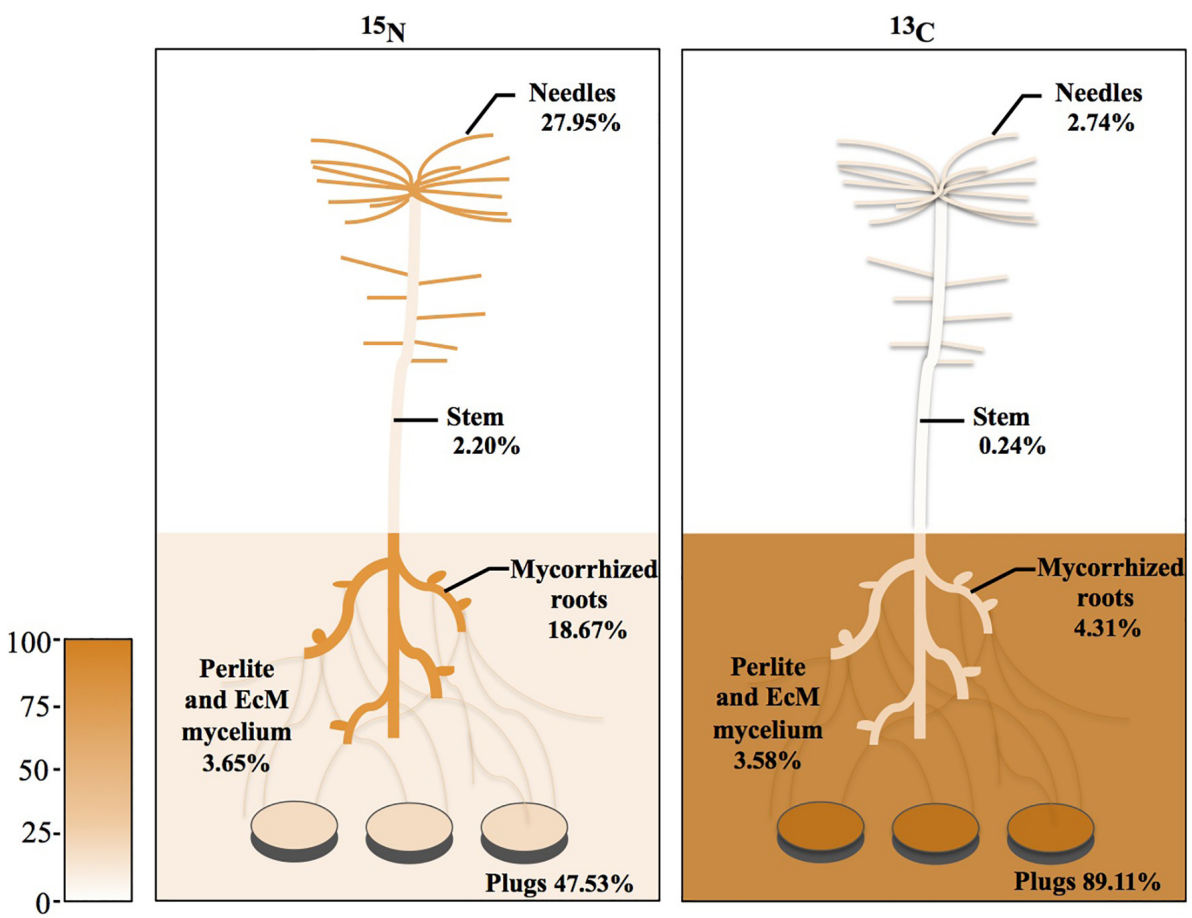

from labelled necromass patches. Over $90 \%$ of this mobilized ${ }^{15} \mathrm{~N}$ was transferred to the tree compartments: EM roots, stem and needles. In contrast, less than $3 \%$ of the ${ }^{13} \mathrm{C}$ (about $27 \%$ of mobilized ${ }^{13} \mathrm{C}$ ) was located in the aboveground part of the tree. Interestingly, in this ${ }^{13} \mathrm{C} /{ }^{15} \mathrm{~N}$ balance model, more than $72.5 \%$ of mobilized ${ }^{13} \mathrm{C}$ was located in roots mycorrhized by $P$. involutus and in its extramatricial mycelium.

\section{Discussion}

The communities of ectomycorrhizal fungi play a major role in plant nutrition and, in recent studies, this fungal ecological group has been described to contribute significantly to the input of carbon into forest carbon pools (Read and Perez-Moreno, 2003; Fernandez et al., 2016). Because EM fungi are part of this important carbon pool in the soil (Clemmensen et al., 2013), the majority of studies have investigated the role of bacteria, or saprotrophic fungi, in the decomposition of the EM fungal necromass (Drigo et al., 2012; Fernandez and Koide, 2012; Russell, 2014; Fernandez et al., 2016). However, there is little evidence on the potential involvement of EM fungi in the degradation of soil necromass compounds, especially fungal or insect cell walls (Klironomos and Hart, 2001; Mucha et al., 2006). In our experiments, we used fungal necromass of $P$. placenta as the sole form of organic nutrients (Di Mario et al., 2008; Hartl et al., 2012; Fernandez and Koide, 2012).

Arising from labelled fungal necromass decomposition, our results demonstrated that $P$. involutus is able to partially decompose the necromass of a ligninolytic fungus and to mobilize $\mathrm{N}$ and $\mathrm{C}$ from this organic matter. Because the necromass was rinsed several times in demineralized water before freeze-drying, we assume that the cells of the brown rot fungus were largely emptied of their cytoplasmic contents and soluble amino acids, disaccharides and monosaccharides. In the present study, the chitin content in $P$. placenta necromass was slightly above the amounts given in the literature for Basidiomycota species, which comprise between 3\% and 11\% (Plassard et al., 1982, Fernandez and Koide, 2012). This chitin can be degraded by two main enzyme groups, designated chitinases and NAGases. If glycoside hydrolase (GH) family 18 endochitinases/exochitinases cleave the chitin chains at random positions to produce chitooligomeres or on either end of the polymer, the $\beta-\mathrm{N}$ acetylglucosaminidase activities (GH20, NAGase), measured in our study, break the released chitobiose into two $\mathrm{N}$-acetylglucosamine monomers (Gaderer et al., 2017). Nevertheless, the enzymatic specificity of 4Methylumbelliferyl N-acetyl- $\beta$-D-glucosaminide is not full, because it could be broken by other enzymes belonging to other glycoside hydrolase or cellulose binding module (CBM) families (Talbot et al., 2015). All together, these results suggest that $P$. involutus could decompose chitin polymers and contribute to the release of associated macromolecules, such as melanin of the cell wall of $P$. placenta, although we cannot rule out that a significant portion of labelled $\mathrm{C} / \mathrm{N}$ was mobilized from lipids, nucleic acids or residual proteins. Subsequent studies, coupling Gas Chromatography or Liquid Chromatography with 
Isotope-ratio mass spectrometry (IRMS) could be conducted to identify the different classes of molecules mobilized by the EM fungus from fungal necromass. In a previous study, Leake and Read (1990) compared the capacity of ericoid and ectomycorrhizal species to degrade crystalline $\alpha$-chitin, suggesting the ability of $P$. involutus to use this crustacean's chitin as a source of nitrogen. Nevertheless, $P$. involutus was much less effective at degrading chitin than ericoid mycorrhizal fungi (Leake and Read, 1990), or than EM Agaricales species (Maillard et al., 2018). Nevertheless, a great variation of chitinases related to nutritional chitin acquisition, competitive interaction, autolysis or cell wall remodelling can be expressed in natural conditions (Kellner and Vandenbol, 2010; Langner and Göhre, 2016). For this reason, only future transcriptomic or proteomic approaches could provide a holistic view of mechanisms involved in fungal necromass degradation, as reported for plant cell walls (Shah et al., 2016). Moreover, $P$. involutus and other EM fungi can also depolymerize proteins and assimilate the released $\mathrm{N}$ from various organic matter sources (Shah et al., 2013). Consequently, the use of labelled pure chitin in future studies would allow to prove the degradation of fungal chitin polymers by $P$. involutus and quantify the proportions of $\mathrm{C}$ and $\mathrm{N}$ potentially mobilized from this polymer. This potential capacity should be checked also for other EM fungi, since some mycorrhizal groups probably have limited capacity to transform organic matter in comparison to certain lineages (Lindahl and Tunlid, 2015; Maillard et al., 2018).

Interestingly, when the EM fungus is in interaction with the host plant, it is still capable of mobilizing nitrogen but also carbon from the Postia necromass. Indeed, the strong accumulation of ${ }^{15} \mathrm{~N}$, especially in the aerial compartments, demonstrated significant transfer of $\mathrm{N}$ from fungal necromass to the plant through the EM fungus. In addition, the ${ }^{15} \mathrm{~N}$ labelling distribution in the plant revealed that the needles were a more relevant $\mathrm{N}$ sink than the roots. Although the EM fungus mainly mines $\mathrm{N}$ from $P$. placenta necromass, it is also able to mobilize C. In contrast, the enrichment in ${ }^{13} \mathrm{C}$ in the host tree was relatively weak, even though the labelling was significant in the needles. Because we have experimentally controlled that this $\mathrm{C}$ labelling was not the result of $P$. involutus respiration $\left(\mathrm{CO}_{2}\right.$ production), these low amounts of fungal $\mathrm{C}$ could come from amino acids or amino sugars, such as glutamine. Indeed, Finlay et al. (1988) reported that several EM fungi were able to assimilate ${ }^{15} \mathrm{~N}$-labelled glutamate/glutamine, with a relatively low supply to the host plant. In pure culture, the significant proportion of ${ }^{13} \mathrm{C}$ measured in the $P$. involutus mycelium revealed for the first time that the EM fungus could mobilize carbon from the $P$. placenta necromass and accumulate it in its mycelium. This original result was supported in the monoxenic symbiotic experiment, by the $\delta^{13} \mathrm{C}$ measurements in the perlite/EM extramatricial mycelium mixture and in pine mycorrhizas that were significantly higher in the samples collected in the labelled condition compared with the 'natural abundance' condition. This experiment reveals that $P$. involutus is able to assimilate $C$ from fungal necromass and integrate it preferentially in its own metabolism with low transfer to the host tree. As suggested by Fellbaum et al. (2014), our study demonstrates how the EM fungus is able to control the interaction, despite being dependent on its host. When the EM fungus is interacting with its host, photosynthetic carbon availability must trigger the decomposition of the fungal organic matter enriched in $\mathrm{N}$ and its assimilation by the symbiotic fungus. However, although the $\mathrm{EM}$ fungus mainly mobilizes $\mathrm{N}$ from this organic matter, it also exploits some of the $C$ available in the necromass. Finally, while this mutualistic symbiosis is based on the reciprocal exchange of tree photosynthetic carbon for fungal-acquired nutrients from organic matter, the fungal partner could compensate for the energetic 'cost' resulting from the degradation of proteins and polymers enriched in $\mathrm{N}$, due to the $\mathrm{C}$ mobilization that results from this decomposition.

A previous study showed that $P$. involutus induced chemical changes in organic compounds from plant material but it would not be able to assimilate released carbon in the presence of polysaccharides and complex cellulolytic compounds (Rineau et al., 2012). In our study, we demonstrated that $P$. involutus was able to assimilate not only $\mathrm{N}$ but also $\mathrm{C}$ from the fungal necromass of a brown rot fungus ( $P$. placenta). Moreover, our experiment highlighted a relevant mobilization of nitrogen and an important transfer toward the trees in symbiotic conditions. These results were obtained in absence of carbon starvation, since the plant host had active photosynthesis. Indeed, it has recently been reported that the $\mathrm{C}$ availability directly drives the nitrogen mobilization of $P$. involutus as well as its activities of litter degradation, but in C-limiting conditions (Rineau et al., 2013). Carbon starvation could induce transcription of the genes encoding laccases, chitinase, peptidases and the transcripts of $\mathrm{N}$-transporters. Moreover, in similar conditions, carbon starvation could induce cell wall material (chitin) release into the medium by $P$. involutus, suggesting that some of the released compounds were re-assimilated by the mycelium (Ellström et al., 2015). This last study provided molecular markers, encoding extracellular enzymes and transporters, that could be used in future experiments to separate both EM functions involved in fungal autolysis and degradation of other fungal necromass in forest soils.

In natural conditions, plant phenology, seasonal carbon reserve dynamics and photosynthetic cycles (winter/summer) regulate the dynamics of soil organic matter 
decomposition by EM fungi and the associated mobilization of $\mathrm{N}$ and possibly $\mathrm{C}$ under certain conditions (Buée et al., 2005; Talbot et al., 2008; Žifčáková et al., 2016). Interestingly, the role of EM fungi in fungal necromass degradation could explain the relative abundance of certain EM fungal species in decayed wood, where they can represent up to $80 \%$ of the fungal community identified during the final phase of the decay process (Rajala et al., 2012, 2015; Angst et al., 2018). Furthermore, these hypotheses are in line with the high chitinase activities measured from the EM root tips sampled in dead woody debris colonized by lignolytic fungi (Buée et al., 2007). These 'scavengers' would act at the end of the degradation process of organic matter in the forest. Finally, the hypothetical fluxes of $\mathrm{C}$ and $\mathrm{N}$ between soil organic matter and plant and fungal components of forest ecosystems should be revisited including non-plant organic matter (Lindahl and Tunlid, 2015). Indeed, EM fungi mobilize $\mathrm{N}$ from the soil organic matter pool, thanks to hydrolytic mechanisms (e.g., proteases, chitinases) and oxidative mechanisms, such as Mn-peroxidases or Fenton reactions, and even if the metabolic $\mathrm{C}$ demand of these symbiotic fungi is not met by organic matter decomposition, some of them could still mobilize $C$ from microbe and soil fauna necromass. Additionally, it is well known that the wood $\mathrm{N}$ content increases during the decay process (Watkinson et al., 2006; Rajala et al., 2012; Rinne et al., 2017). This accumulation rate of $\mathrm{N}$ at the end of wood degradation would promote the development of EM fungi, but also the establishment of competition with saprotrophic fungi. An increase in the relative abundance of EM fungi in these late stages of decay could decrease decomposition of wood by limiting nitrogen access for saprotrophs - as a 'Gadgil effect' (Gadgil and Gadgil, 1971). Coupled with recent observations (Mäkipää et al., 2017; Maillard et al., 2018), our results illustrate the complexity of trophic networks in forest soil and microbial competitions for nutrient mobilization. The coupling of controlled studies, targeting other EM fungi, with field observations may be helpful in future investigations. It will be necessary to demonstrate the fungal necromass degradation ability and the ecological role of specific wood-inhabiting EM fungi, particularly the dominant genera in late stages of degradation, such as Tylospora, Piloderma, Lactarius, Russula or Tomentella (Buée et al., 2007; Rajala et al., 2012; Mäkipää et al., 2017). The goal of these future studies will be to bridge the current gap between genetic studies in the laboratory, in particular on genes and molecular processes involved in microbial cell wall degradation and mechanisms of speciation for these specific EM species, and field studies on interactions between organisms in their natural environment. Taking the role of EM fungi in microbial necromass degradation into consideration, we should improve our understanding of the role of EM fungi in forest $\mathrm{C}$ and $\mathrm{N}$ cycles, and modulate the paradigm of mycorrhizal symbiosis by revisiting the $\mathrm{C}$ organic market in this plantfungus interaction.

\section{Experimental procedures}

\section{Experimental design}

Nutrient transfers were traced by ${ }^{15} \mathrm{~N}$ and ${ }^{13} \mathrm{C}$ enrichment of saprotrophic fungal necromass. Two separate experiments were carried out. In the first experiment, Paxillus involutus (strain $\mathrm{Pi}$ 01) was grown in sterilized pure liquid culture enriched with or without the necromass of a saprotrophic fungus ( $P$. placenta, strain PP978/9). We measured the ${ }^{15} \mathrm{~N}$ and ${ }^{13} \mathrm{C}$ enrichment in $P$. involutus and the extracellular chitinolytic activities ( $\mathrm{N}$-acetylglucosaminidase) of this EM fungal model. In the second experiment, we used a monoxenic system with Pinus sylvestris seedlings inoculated with $P$. involutus in the presence or absence of $P$. placenta necromass. The transfers of ${ }^{15} \mathrm{~N}$ and ${ }^{13} \mathrm{C}$ from the saprotroph necromass were measured in above- and belowground mycorrhized plant compartments including root tips and extramatricial mycelium in the mineral substrate (perlite). This monoxenic dual culture was maintained in plastic Magenta boxes, previously autoclave sterilized. A control was added to measure the potential exchange of ${ }^{13} \mathrm{CO}_{2}$ within the Magenta box atmosphere (Supporting Information Fig. S2). Both experimental ways are explained in detail in the following sections.

\section{Biological resources and P. placenta necromass production}

Pure cultures of fungal material: Paxillus involutus and Postia placenta. In sterile conditions, the EM fungus Paxillus involutus was cultured in Petri dishes at $20^{\circ} \mathrm{C}$ in the dark on modified Melin-Norkrans (MMN) medium (Marx, 1969), without malt extract: $10 \mathrm{mg} \mathrm{l}{ }^{-1} \mathrm{KH}_{2} \mathrm{PO}_{4},\left(\mathrm{NH}_{4}\right)_{2} \mathrm{HPO}_{4}, \mathrm{CaCl}_{2}$ $\left(\mathrm{H}_{2} \mathrm{O}\right)_{2}, \mathrm{NaCl}, \mathrm{MgSO}_{4}\left(\mathrm{H}_{2} \mathrm{O}\right)_{2}$, thiamine $\left(100 \mathrm{mg} \mathrm{l}^{-1}\right), \mathrm{FeCl}_{3} \cdot 6$

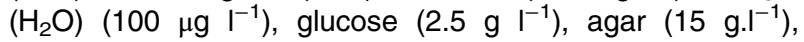
$\mathrm{pH}$ 5.5. The brown-rot fungus $P$. placenta was cultured in liquid medium comprised of $7 \mathrm{~g} \mathrm{I}^{-1}$ glucose, $3 \mathrm{~g} \mathrm{I}^{-1}\left(\mathrm{NH}_{4}\right)_{2} \mathrm{SO}_{4}$, $2 \mathrm{~g} \mathrm{I}^{-1}$ of $\mathrm{KH}_{2} \mathrm{PO}_{4}, 0.4 \mathrm{~g} \mathrm{I}^{-1}$ of $\mathrm{MgSO}_{4} \cdot 7\left(\mathrm{H}_{2} \mathrm{O}\right), 1 \mathrm{mg} \mathrm{I}^{-1}$ Thiamine $\mathrm{HCl}$ and $1 \mathrm{ml}$ of microelement solution adjusted to $\mathrm{pH} 5$, then autoclaved. The microelement solution contained: $\mathrm{MnCl}_{2}\left(\mathrm{H}_{2} \mathrm{O}\right)_{4}\left(6 \mathrm{mg} \mathrm{l}^{-1}\right), \mathrm{H}_{3} \mathrm{BO}_{3}\left(1.5 \mathrm{mg} \mathrm{l}{ }^{-1}\right), \mathrm{ZnSO}_{4} \cdot 7$ $\left(\mathrm{H}_{2} \mathrm{O}\right)\left(2.65 \mathrm{~g} \mathrm{I}^{-1}\right), \mathrm{KCl}\left(0.75 \mathrm{~g} \mathrm{I}^{-1}\right), \mathrm{Na}_{2} \mathrm{MoO}_{4} \cdot 2\left(\mathrm{H}_{2} \mathrm{O}\right)$ $\left(0.0024 \mathrm{mg} \mathrm{l}^{-1}\right), \mathrm{CuSO}_{4} \cdot 5\left(\mathrm{H}_{2} \mathrm{O}\right)\left(0.13 \mathrm{mg} \mathrm{l}^{-1}\right)$.

For the labelled/unlabelled biomass production of $P$. placenta, the fungus was grown in sterile conditions during 3 months in Erlenmeyer flasks $(500 \mathrm{ml})$, providing about $1 \mathrm{~g} \mathrm{I}^{-1}$ of dry weight after filtration. P. placenta was selected because the EM fungus $P$. involutus expressed higher $\mathrm{N}$ acetylglucosaminidase activity in the presence of the $P$. placenta necromass during a previous screening 
comparing 12 different lignolytic fungal strains: six brown rot fungi and six white rot fungi (data not shown). Moreover, as result of a pilot enrichment study focusing on a ${ }^{15} \mathrm{~N}$ and ${ }^{13} \mathrm{C}$ labelling range of $P$. placenta, the fungus was cultivated in the presence of ammonium sulfate enriched with ${ }^{15} \mathrm{~N}$ and ${ }^{13} \mathrm{C}$ glucose (the first carbon of the glucose was labelled) to obtain a final isotopic abundance close to 2 atom $\%$ of ${ }^{15} \mathrm{~N}$ and 15 atom $\%$ for ${ }^{13} \mathrm{C}$. After 3 months of culturing, the labelled biomass of $P$. placenta was thoroughly rinsed with sterile distilled water (10 washes), freeze-dried and ground. The mycelium powder was directly used as substrate for the $P$. involutus pure cultures for enzymatic tests or incorporated into agar plugs $(0.5 \mathrm{~g}$ for $100 \mathrm{ml})$ for the controlled mycorrhization experiments in plastic Magenta boxes. The unlabelled $P$. placenta necromass (control) was produced under the same conditions using unlabelled glucose and $\mathrm{NH}_{4}$ sulfate. Finally, the mean enrichment in the labelled $P$. placenta mycelium was $\delta 13 \mathrm{C}=434.34 \%$ and $\delta 15 \mathrm{~N}=5074.52 \%$; and the natural abundance for unlabelled mycelium was $\delta 13 \mathrm{C}=-17.34 \%$ and $\delta 15 \mathrm{~N}=7.93 \%$. This mycelium powder was produced under sterile conditions through the whole process.

Proteins and chitin quantification from P. placenta necromass. Soluble proteins were extracted from lyophilized $P$. placenta necromass. Briefly, $20 \mathrm{mg}$ were mixed with $400 \mu \mathrm{l}$ of the extraction buffer [Tris $\mathrm{HCl} 62.5 \mathrm{mM} \mathrm{pH} 6.8$, SDS2\% (v/v), Glycerol 10\% and DTT $28 \mathrm{mM}$ ] with a vortex every $15 \mathrm{~min}$ for $1 \mathrm{~h}$. Samples were centrifuged twice at $14000 \mathrm{rpm}$ for $15 \mathrm{~min}$ (at room temperature). The protein concentration was determined according to RC-DC Protein Assay (RC DC Protein Assay 500-0121, Biorad, Hercules, CA, USA) and expressed as $\mathrm{mg}$ of protein per $\mathrm{g}$ of dry $P$. placenta necromass. Chitin content of the $P$. placenta mycelium was assayed colorimetrically using methods developed by Chen and Johnson (1983). In short, $8 \mathrm{mg}$ of necromass was hydrolyzed for $4 \mathrm{~h}$ at $100^{\circ} \mathrm{C}$ with $6 \mathrm{M}$ hydrochloric acid. The hydrolysate was then filtrated, evaporated and redissolved in distilled water. Colorimetric assay was conducted exactly as detailed in Chen and Johnson (1983). Chitin content was expressed in $\%$ of dry $P$. placenta necromass, with an adjustment of $9 \%$ for loss due to hydrolysis (calculated in this study).

Plant growth conditions and fungal inoculation. First, plastic Magenta boxes were sterilized, hermetically closed and filled with $170 \mathrm{ml}$ of sterilized perlite, an inert mineral substrate poor in carbon $(0.03 \%)$ and nitrogen $(0.006 \%)$. In each box, the perlite substrate was then inoculated with 4 agar plugs colonized by $P$. involutus. During this transfer, $70 \mathrm{ml}$ modified MMN liquid medium (without malt extract) was added to improve the growth of the fungus. In parallel, Scots pine seeds were surface-sterilized with $50 \%$ hydrogen peroxide $\left(\mathrm{H}_{2} \mathrm{O}_{2}\right)$ for $30 \mathrm{~min}$, rinsed in distilled water and pregerminated aseptically on water agar Petri plates (agar $10 \mathrm{~g}$ $\mathrm{I}^{-1}$ ) at $20^{\circ} \mathrm{C}$ under a 16-h photoperiod (Heller et al., 2008). After 7 days, the Scots pine seedlings were transferred into Magenta boxes in which the sterile perlite substrate had been previously colonized by $P$. involutus. After 4 months of incubation in growth chamber at $24^{\circ} \mathrm{C}$ with a 16 -h photoperiod providing approximately $275 \mu \mathrm{mol} \mathrm{m} \mathrm{m}^{-2} \mathrm{~s}^{-1}$, we observed an abundant development of lateral roots on the pines inoculated with $P$. involutus and the formation of the first mycorrhizae (Supporting Information Fig. S3). Fungal necromass was then introduced into Magenta boxes under sterile conditions (mycelium powder incorporated into agar plugs). In each box, four patches were positioned on the surface of the perlite layer, providing approximately $30 \mathrm{mg}$ dry organic matter per box. Two treatments were initiated: a 'labelled' condition with patches containing labelled ${ }^{13} \mathrm{C}$ and ${ }^{15} \mathrm{~N}$ necromass and a control condition with unlabelled patches. In addition, to control for a potential ${ }^{13} \mathrm{CO}_{2}$ flux (EM fungus respiration), a third condition (gas control) was introduced in this experiment (Supporting Information Fig. S2). One plastic Magenta box containing a non-mycorrhized seedling, without necromass patch was connected to another Magenta box containing a mycorrhized seedling in presence of labelled necromass $(n=3)$.

All the treatments were maintained for 6 months at $24{ }^{\circ} \mathrm{C}$ with a 16-h photoperiod providing approximately $275 \mu \mathrm{mol}$ $\mathrm{m}^{-2} \mathrm{~s}^{-1}$ (four lights $-4 \times 58 \mathrm{~W}$ per shelf), and the sterile conditions were regularly inspected. At the end of the experiment, plants were harvested, and the ectomycorrhizal root tips were sampled under a stereomicroscope, excluding the biological material in direct contact with the labelled patches. Moreover, needles, stems and the perlite colonized with $P$. involutus mycelium were carefully collected.

\section{Extracellular $N$-acetylglucosaminidase activity of $P$. involutus in the response of $P$. placenta necromass in pure culture}

Extracellular exo-chitinolytic activity of $P$. involutus was measured in pure culture in the presence or absence of labelled and unlabelled saprotrophic fungal necromass. For this experiment, $P$. involutus was grown in autoclaved liquid medium comprising: $1 \mathrm{~g} \mathrm{I}^{-1}$ glucose, $0.1 \mathrm{~g} \mathrm{I}^{-1}$ of $\left(\mathrm{NH}_{4}\right)_{2} \mathrm{C}_{4} \mathrm{H}_{4} \mathrm{O}_{6}, 1 \mathrm{~g} \mathrm{I}^{-1}$ of $\mathrm{KH}_{2} \mathrm{PO}_{4}, 0.5 \mathrm{~g} \mathrm{I}^{-1}$ of $\mathrm{MgSO}_{4} \cdot 7$ $\left(\mathrm{H}_{2} \mathrm{O}\right)$ and $1 \mathrm{ml}$ of microelement solution (see above). This medium was adjusted to $\mathrm{pH} 5$ and autoclaved. $P$. placenta necromass (20 mg of powder) was added to $40 \mathrm{ml}$ of the sterile medium to give a final concentration of $500 \mathrm{mg}$ of necromass per litre of liquid medium. A total of $2.4 \mathrm{ml}$ of liquid medium with unlabelled necromass and liquid medium with labelled necromass was dispensed in a 6-well cell culture plate. From Petri dishes culture (MMN medium), fungal disks $(5 \mathrm{~mm})$ of $P$. involutus were cut close to the growth hyphal front and placed in each well ( $n=6$ wells per treatment). The EM fungus was grown in these wells on a layer of autoclaved glass beads immersed in liquid medium complemented with $P$. placenta necromass. After 20 days of growth at $20^{\circ} \mathrm{C}$ in the dark, the liquid medium of the living $P$. involutus treatments was collected for $\mathrm{N}$-acetylglucosaminidase assay, and the fungal material was sampled separately for isotopic analyses (see below). Moreover, to check potential ${ }^{15} \mathrm{~N}$ and ${ }^{13} \mathrm{C}$ labelling contamination resulting from passive adsorption of the labelled material ( $P$. placenta powder) 
on the EM fungus mycelium, in another treatment $P$. involutus mycelium patches were also freeze-dried and introduced in cell culture plates ( $n=4$ wells per treatment). In the same way as for living $P$. involutus mycelia, after 20 days, the dead $P$. involutus disks were collected for isotopic analyses (see below).

$\mathrm{N}$-acetylglucosaminidase activities were measured with enzymatic fluorescence microplate assays adapted from Pritsch et al., (2004). Briefly, $200 \mu \mathrm{l}$ of $P$. involutus liquid culture was centrifuged $(4500 \mathrm{~g})$ for $5 \mathrm{~min}$. One hundred microlitres of the supernatant was transferred to a 96-well plate and incubated with $100 \mu$ acetate buffer $(\mathrm{pH}=5$, $28.82 \mathrm{ml} 1 \mathrm{M}$ acetic acid, $273.3 \mathrm{ml} 0.3 \mathrm{M}$ sodium acetate and $1 \mathrm{I}$ distilled water) and $50 \mu \mathrm{l}$ exo-chitinase substrate, MU-N-acetyl- $\beta$-D-glucosaminide, diluted in acetate buffer $(\mathrm{pH}=5)$. After $40 \mathrm{~min}$ incubation at $23^{\circ} \mathrm{C}, 100 \mu$ l stopping buffer (Tris $2.5 \mathrm{M}, \mathrm{pH} \mathrm{10-11)} \mathrm{was} \mathrm{added} \mathrm{with} 100 \mu \mathrm{l}$ of the incubation solutions. Finally, $100 \mu$ of this solution was transferred to reading plates. Measurements were performed with a microplate reader Victor3 (Wallac Perkin-Elmer Life Sciences, Villebon-Sur-Yvette, France). The measured fluorescence was expressed in pmol of 4-methylumbelliferone formed by $\mathrm{ml}$ of culture medium per min. Since the fungal necromass could conserve residual extracellular enzymatic activities, we also measured the $\mathrm{N}$-acetylglucosaminidase basal activity of the fungal necromass (Brábcová et al., 2016).

\section{Isotopic measurement}

Isotopic analysis. The analyses of ${ }^{15} \mathrm{~N}$ and ${ }^{13} \mathrm{C}$ isotopes were processed using an online continuous flow $\mathrm{CN}$ analyzer (Carlo Erba NA1500, Italy) coupled with an isotope ratio mass spectrometer (Finnigan delta S, Bremen, Germany). Values were reported in the standard notation $\left(\delta^{13} \mathrm{C} \%\right.$ and $\delta^{15} \mathrm{~N} \%$ ) relative to Pee-Dee Belemnite for $\mathrm{C}$, using and polyethylene foil (IAEA-CH-7) provided by the International Atomic Energy Agency as a standard, and relative to atmospheric $\mathrm{N}_{2}$ for $\mathrm{N}$, using $\left(\mathrm{NH}_{4}\right)_{2} \mathrm{SO}_{4}$ (IAEA-N-1) as a standard. $\left.\delta X=\left(R_{\text {sample }} / R_{\text {standard }}\right)-1\right) \times 1000$, where $R$ is the molar ratio heavy $X /{ }^{\text {light }} X$ (Zeller et al., 2008).

Incorporation of the brown-rot fungal necromass by EM fungus in pure culture. The living mycelium of $P$. involutus and the freeze-dried mycelium patches used for the $\mathrm{N}$ acetylglucosaminidase assay were collected and placed in a 6 -well culture plate with distilled water and agitated during $1 \mathrm{~h}$ to remove any necromass fragments. This washing step was repeated five times. Then, dead (patches) and living mycelia were freeze-dried, weighed and used for the isotope analyses. The isotope analyses were conducted on dead and living mycelia of $P$. involutus from the pure culture experiment to measure the direct incorporation of ${ }^{15} \mathrm{~N}$ and ${ }^{13} \mathrm{C}$ in the $\mathrm{EM}$ fungus from the $P$. placenta necromass.

Estimation of nutrient transfer from necromass to EM plant in monoxenic conditions. In the mycorrhized pine experiment containing labelled ${ }^{13} \mathrm{C}$ and ${ }^{15} \mathrm{~N}$ necromass, the isotopic enrichment was measured in the four biological compartments: needles, stems, mycorrhized roots and the perlite colonized by the mycelium of $P$. involutus. The isotopic enrichment was also quantified in the agar patches containing the lignolytic fungal necromass before and after consumption by the ectomycorrhizal fungus to provide the proportion of $\mathrm{N}$ and $\mathrm{C}$ mobilized during the experiment. Data were collected as atom percentage ${ }^{13} \mathrm{C}$ and ${ }^{15} \mathrm{~N}$ and as percentage $\mathrm{C}$ and $\mathrm{N}$ (relative abundance $-\delta \%$ ). The excess mass of ${ }^{13} \mathrm{C}$ and ${ }^{15} \mathrm{~N}$ was calculated separately using mean biomass of roots, stems and needles. Biomass $P$. involutus mycelium within the perlite could not be measured. Because this value was extremely low in comparison to plant biomass, the proportions of $\mathrm{C}$ and $\mathrm{N}$ mobilization were estimated by the difference in relative abundance $(\delta \% \circ)$ between labelled and unlabelled perlite/mycelium mixture.

\section{Statistics}

Statistical analyses were conducted with the $\mathrm{R}$ software (R Core Team, 2016). Variables expressed as $\delta^{13} \mathrm{C}(\%)$ and $\delta^{15} \mathrm{~N}$ (\%) were analyzed using Kruskal-Wallis test by ranks and Wilcoxon signed-rank test. The threshold of significance was fixed for $p$-value $<0.05$, with three levels of significance ( $p$-value $<0.05^{*}, p$-value $<0.01^{* *}, p$-value $\left.<0.001^{* \star *}\right)$. Similarly, enzymatic activities were statistically analyzed using Kruskal-Wallis test by ranks.

\section{Acknowledgements}

This work was supported by a grant overseen by the French National Research Agency (ANR) as part of the 'Investissements d'Avenir' program (ANR-11-LABX-0002-01, Lab of Excellence ARBRE). FM holds a PhD fellowship awarded by the Région Lorraine and the Laboratory of excellence ARBRE (BRIDGE project). American Journal Experts association revised the language of the manuscript. M.B. coordinated the project, planned and designed the research. E.A., F.M. and C.B. performed all experiments. C.H., C.B. and N.A. planned the isotopic analyses and C.H. processed isotopic measurements. M.B., C.B., E.A. and F.M. analyzed data. M.B., E.A. and F.M. wrote the manuscript. All authors participated in the proofreading. E.A and F.M. contributed equally to this work. The authors thank the three anonymous reviewers for their helpful comments.

\section{References}

Angst, Š., Baldrian, P., Harantová, L., Cajthaml, T., and Frouz, J. (2018) Different twig litter (Salix caprea) diameter does affect microbial community activity and composition but not decay rate. FEMS Microbiol Ecol 94. https:// doi.org/10.1093/femsec/fiy126.

Bartnicki-Garcia, S. (1968) Cell wall chemistry, morphogenesis, and taxonomy of fungi. Annu Rev Microbiol 22: 87-108.

Blanchette, R. A. (1995) Degradation of the lignocellulose complex in wood. Can J Bot 73: 999-1010. 
Boschker, H. T. S., and Middelburg, J. J. (2002) Stable isotopes and biomarkers in microbial ecology. FEMS Microbiol Ecol 40: 85-95.

Brábcová, V., Nováková, M., Dávidová, A., and Baldrian, P. (2016) Dead fungal mycelium in forest soil represents a decomposition hotspot and a habitat for a specific microbial community. New Phytol 210: 1369-1381.

Bréda, N., Maillard, P., Montpied, P., Bréchet, C., Garbaye, J., and Courty, P. E. (2013) Isotopic evidence in adult oak trees of a mixotrophic lifestyle during spring reactivation. Soil Biol Biochem 58: 136-139.

Buée, M., Vairelles, D., and Garbaye, J. (2005) Year-round monitoring of diversity and potential metabolic activity of the ectomycorrhizal community in a beech (Fagus silvatica) forest subjected to two thinning regimes. Mycorrhiza 15: 235-245.

Buée, M., Courty, P. E., Mignot, D., and Garbaye, J. (2007) Soil niche effect on species diversity and catabolic activities in an ectomycorrhizal fungal community. Soil Biol Biochem 39: 1947-1955.

Chen, G. C., and Johnson, B. R. (1983) Improved colorimetric determination of cell wall chitin in wood decay fungi. Appl Environ Microbiol 46: 13-16.

Clemmensen, K. E., Bahr, A., Ovaskainen, O., Dahlberg, A., Ekblad, A., Wallander, H., et al. (2013) Roots and associated fungi drive long-term carbon sequestration in boreal forest. Science 339: 1615-1618.

Courty, P. E., Bréda, N., and Garbaye, J. (2007) Relation between oak tree phenology and the secretion of organic matter degrading enzymes by Lactarius quietus ectomycorrhizas before and during bud break. Soil Biol Biochem 39: 1655-1663.

Cullings, K., and Courty, P. E. (2009) Saprotrophic capabilities as functional traits to study functional diversity and resilience of ectomycorrhizal community. Oecologia 161: 661-664.

Di Mario, F., Rapana, P., Tomati, U., and Galli, E. (2008) Chitin and chitosan from Basidiomycetes. Int $J$ Biol Macromol 43: 8-12.

Drigo, B., Anderson, I. C., Kannangara, G. S. K., Cairney, J. W., and Johnson, D. (2012) Rapid incorporation of carbon from ectomycorrhizal mycelial necromass into soil fungal communities. Soil Biol Biochem 49: 4-10.

Durall, D. M., Todd, A. W., and Trappe, J. M. (1994) Decomposition of 14C-labeled substrates by ectomycorrhizal fungi in association with Douglas fir. New Phytol 127: 725-729.

Ellström, M., Shah, F., Johansson, T., Ahrén, D., Persson, P., and Tunlid, A. (2015) The carbon starvation response of the ectomycorrhizal fungus Paxillus involutus. FEMS Microbiol Ecol 91: fiv027.

Fellbaum, C. R., Mensah, J. A., Cloos, A. J., Strahan, G. E., Pfeffer, P. E., Kiers, E. T., and Bücking, H. (2014) Fungal nutrient allocation in common mycorrhizal networks is regulated by the carbon source strength of individual host plants. New Phytol 203: 646-656.

Fernandez, C. W., and Koide, R. T. (2012) The role of chitin in the decomposition of ectomycorrhizal fungal litter. Ecology 93: 24-28.

Fernandez, C. W., Langley, J. A., Chapman, S., McCormack, M. L., and Koide, R. T. (2016) The decomposition of ectomycorrhizal fungal necromass. Soil Biol Biochem 93: 38-49.
Finlay, R. D., Ek, H., Odham, G., and Söderström, B. (1988) Mycelial uptake, translocation and assimilation of nitrogen from $15 \mathrm{~N}$-labelled ammonium by Pinus sylvestris plants infected with four different ectomycorrhizal fungi. New Phytol 110: 59-66.

Gaderer, R., Seidl-Seiboth, V., and Kappel, L. (2017) Chitin and $\mathrm{N}$-acetylglucosamine metabolism in fungi-a complex machinery harnessed for the design of chitin-based high value products. Curr Biotechnol 6: 178-193.

Gadgil, R. L., and Gadgil, P. D. (1971) Mycorrhiza and litter decomposition. Nature 233: 133.

Godbold, D. L., Hoosbeek, M. R., Lukac, M., Cotrufo, M. F., Janssens, I. A., Ceulemans, R., et al. (2006) Mycorrhizal hyphal turnover as a dominant process for carbon input into soil organic matter. Plant Soil 281: 15-24.

Hartl, L., Zach, S., and Seidl-Seiboth, V. (2012) Fungal chitinases: diversity, mechanistic properties and biotechnological potential. Appl Microbiol Biotechnol 93: 533-543.

Heller, G., Adomas, A., Li, G., Osborne, J., van Zyl, L., Sederoff, R., et al. (2008) Transcriptional analysis of Pinus sylvestris roots challenged with the ectomycorrhizal fungus Laccaria bicolor. BMC Plant Biol 8: 19.

Hodge, A., Alexander, I. J., and Gooday, G. W. (1995) Chitinolytic enzymes of pathogenic and ectomycorrhizal fungi. Mycol Res 99: 935-941.

Kellner, H., and Vandenbol, M. (2010) Fungi unearthed: transcripts encoding lignocellulolytic and chitinolytic enzymes in forest soil. PLoS One 5: e10971.

Klironomos, J. N., and Hart, M. M. (2001) Food-web dynamics: animal nitrogen swap for plant carbon. Nature 410: 651-652.

Kögel-Knabner, I. (2002) The macromolecular organic composition of plant and microbial residues as inputs to soil organic matter. Soil Biol Biochem 34: 139-162.

Kohler, A., Kuo, A., Nagy, L. G., Morin, E., Barry, K. W., Buscot, F., et al. (2015) Convergent losses of decay mechanisms and rapid turnover of symbiosis genes in mycorrhizal mutualists. Nature Genetics 47: 410.

Kruys, N., and Jonsson, B. G. (1999) Fine woody debris is important for species richness on logs in managed boreal spruce forests of northern Sweden. Can J For Res 29: 1295-1299.

Kumar, M. N. R. (2000) A review of chitin and chitosan applications. React Funct Polym 46: 1-27.

Langner, T., and Göhre, V. (2016) Fungal chitinases: function, regulation, and potential roles in plant/pathogen interactions. Curr Genet 62: 243-254.

Leake, J. R., and Read, D. J. (1990) Chitin as a nitrogen source for mycorrhizal fungi. Mycol Res 94: 993-995.

Lindahl, B. D., and Finlay, R. D. (2006) Activities of chitinolytic enzymes during primary and secondary colonization of wood by basidiomycetous fungi. New Phytol 169: 389-397.

Lindahl, B. D., and Taylor, A. F. (2004) Occurrence of Nacetylhexosaminidase-encoding genes in ectomycorrhizal basidiomycetes. New Phytol 164: 193-199.

Lindahl, B. D., and Tunlid, A. (2015) Ectomycorrhizal fungi potential organic matter decomposers, yet not saprotrophs. New Phytol 205: 1443-1447.

Lorenz, K., Lal, R., Preston, C. M., and Nierop, K. G. (2007) Strengthening the soil organic carbon pool by increasing contributions from recalcitrant aliphatic bio (macro) molecules. Geoderma 142: 1-10. 
Maillard, F., Didion, M., Fauchery, L., Bach, C., and Buée, M. (2018) N-Acetylglucosaminidase activity, a functional trait of chitin degradation, is regulated differentially within two orders of ectomycorrhizal fungi: Boletales and Agaricales. Mycorrhiza 28: 391-397.

Mäkipää, R., Rajala, T., Schigel, D., Rinne, K. T., Pennanen, T., Abrego, N., and Ovaskainen, O. (2017) Interactions between soil-and dead wood-inhabiting fungal communities during the decay of Norway spruce logs. ISME J 11: 1964-1974.

Marx, D. H. (1969) The influence of ectotrophic mycorrhizal fungi on the resistance of pine roots to pathogenic infections. I. Antagonism of mycorrhizal fungi to root pathogenic fungi and soil bacteria. Phytopathology 59: 153-163.

Mucha, J., Dahm, H., Strzelczyk, E., and Werner, A. (2006) Synthesis of enzymes connected with mycoparasitism by ectomycorrhizal fungi. Arch Microbiol 185: 69-77.

Mucha, J., Dahm, H., and Werner, A. (2007) Influence of autoclaved saprotrophic fungal mycelia on proteolytic activity in ectomycorrhizal fungi. Antonie van Leeuwenhoek 92: 137-142.

Nannipieri, P., and Eldor, P. (2009) The chemical and functional characterization of soil $\mathrm{N}$ and its biotic components. Soil Biol Biochem 41: 2357-2369.

Nordén, B., Ryberg, M., Götmark, F., and Olausson, B. (2004) Relative importance of coarse and fine woody debris for the diversity of wood-inhabiting fungi in temperate broadleaf forests. Biol Conserv 117: 1-10.

Plassard, C. S., Mousain, D. G., and Salsac, L. E. (1982) Estimation of mycelial growth of basidiomycetes by means of chitin determination. Phytochemistry 21: 345-348.

Pritsch, K., Raidl, S., Marksteiner, E., Blaschke, H., Agerer, R., Schloter, M., and Hartmann, A. (2004) A rapid and highly sensitive method for measuring enzyme activities in single mycorrhizal tips using 4-methylumbelliferonelabeled fluorogenic substrates in a microplate system. $J$ Microbiol Methods 58: 233-241.

$\mathrm{R}$ Core Team. (2016) R: A Language and Environment for Statistical Computing. Vienna, Austria: R Foundation for Statistical Computing. http://www.R-project.org/.

Rajala, T., Peltoniemi, M., Pennanen, T., and Mäkipää, R. (2012) Fungal community dynamics in relation to substrate quality of decaying Norway spruce (Picea abies [L.] karst.) logs in boreal forests. FEMS Microbiol Ecol 81: 494-505.

Rajala, T., Tuomivirta, T., Pennanen, T., and Mäkipää, R. (2015) Habitat models of wood-inhabiting fungi along a decay gradient of Norway spruce logs. Fungal Ecol 18: 48-55.

Read, D. J., and Perez-Moreno, J. (2003) Mycorrhizas and nutrient cycling in ecosystems-a journey towards relevance? New Phytol 157: 475-492.

Rineau, F., Roth, D., Shah, F., Smits, M., Johansson, T., Canbäck, B., et al. (2012) The ectomycorrhizal fungus Paxillus involutus converts organic matter in plant litter using a trimmed brown-rot mechanism involving Fenton chemistry: organic matter degradation by ectomycorrhizal fungi. Environ Microbiol 14: 1477-1487.

Rineau, F., Shah, F., Smits, M. M., Persson, P., Johansson, T., Carleer, R., et al. (2013) Carbon availability triggers the decomposition of plant litter and assimilation of nitrogen by an ectomycorrhizal fungus. ISME J 7: 2010-2022.

Rinne, K. T., Rajala, T., Peltoniemi, K., Chen, J., Smolander, A., and Mäkipää, R. (2017) Accumulation rates and sources of external nitrogen in decaying wood in a Norway spruce dominated forest. Funct Ecol 3: 530-541.

Russell, A. E. (2014) Unexpected effects of chitin, cellulose, and lignin addition on soil dynamics in a wet tropical forest. Ecosystems 17: 918-930.

Schmidt, M. W., Torn, M. S., Abiven, S., Dittmar, T., Guggenberger, G., Janssens, I. A., et al. (2011) Persistence of soil organic matter as an ecosystem property. Nature 478: 49-56.

Shah, F., Rineau, F., Canbäck, B., Johansson, T., and Tunlid, A. (2013) The molecular components of the extracellular protein-degradation pathways of the ectomycorrhizal fungus Paxillus involutus. New Phytol 200: 875-887.

Shah, F., Nicolás, C., Bentzer, J., Ellström, M., Smits, M., Rineau, F., et al. (2016) Ectomycorrhizal fungi decompose soil organic matter using oxidative mechanisms adapted from saprotrophic ancestors. New Phytol 209: 1705-1719.

Six, J., Frey, S. D., Thiet, R. K., and Batten, K. M. (2006) Bacterial and fungal contributions to carbon sequestration in agroecosystems. Soil Sci Soc Am J 70: 555-569.

Smith, S. E., and Read, D. J. (2010) Mycorrhizal Symbiosis. London: Academic Press.

Stockland, J. N., Siitonen, J., and Jonsson, B. G. (2012) Biodiversity in Dead Wood. Cambridge: Cambridge University Press, pp. 29-57.

Talbot, J. M., Allison, S. D., and Treseder, K. K. (2008) Decomposers in disguise: mycorrhizal fungi as regulators of soil $\mathrm{C}$ dynamics in ecosystems under global change. Funct Ecol 22: 955-963.

Talbot, J. M., Bruns, T. D., Smith, D. P., Branco, S., Glassman, S. I., Erlandson, S., et al. (2013) Independent roles of ectomycorrhizal and saprotrophic communities in soil organic matter decomposition. Soil Biol Biochem 57: 282-291.

Talbot, J. M., Martin, F., Kohler, A., Henrissat, B., and Peay, K. G. (2015) Functional guild classification predicts the enzymatic role of fungi in litter and soil biogeochemistry. Soil Biol Biochem 88: 441-456.

Tedersoo, L., Kõljalg, U., Hallenberg, N., and Larsson, K. H. (2003) Fine scale distribution of ectomycorrhizal fungi and roots across substrate layers including coarse woody debris in a mixed forest. New Phytol 159: 153-165.

Vaario, L. M., Guerin-Laguette, A., Matsushita, N., Suzuki, K., and Lapeyrie, F. (2002) Saprobic potential of Tricholoma matsutake: growth over pine bark treated with surfactants. Mycorrhiza 12: 1-5.

Walker, J. K. M., Ward, V., Paterson, C., and Jones, M. D. (2012) Coarse woody debris retention in subalpine clearcuts affects ectomycorrhizal root tip community structure within fifteen years of harvest. Appl Soil Ecol 60: 5-15.

Watkinson, S. C., Bebber, D., Darrah, P., Fricker, M., Tlalka, M., and Boddy, L. (2006)The role of wood decay fungi in the carbon and nitrogen dynamics of the forest floor . In Fungi in Biogeochemical Cycles, Gadd, G. M. (ed). Cambridge: Cambridge University Press, pp. 151-181. Werner, G. D., Strassmann, J. E., Ivens, A. B., Engelmoer, D. J., Verbruggen, E., Queller, D. C., et al. 
(2014) Evolution of microbial markets. Proc Natl Acad Sci U S A 111: 1237-1244.

Zeller, B., Bréchet, C., Maurice, J. P., and Le Tacon, F. (2008) Saprotrophic versus symbiotic strategy during truffle ascocarp development under holm oak. A response based on ${ }^{13} \mathrm{C}$ and ${ }^{15} \mathrm{~N}$ natural abundance. Ann Forest Sci 65: 607-617.

Žifcáková, L., Větrovský, T., Howe, A., and Baldrian, P. (2016) Microbial activity in forest soil reflects the changes in ecosystem properties between summer and winter. Environ Microbiol 18: 288-301.

\section{Supporting Information}

Additional Supporting Information may be found in the online version of this article at the publisher's web-site:

Figure S1. Chitinase (N-acetylglucosaminidase) activities of Paxillus involutus cultivated in the presence or absence of labelled and unlabelled saprotrophic fungal necromass from $P$. placenta ( $n=6$ in each condition). Differences in $\mathrm{N}$-acetylglucosamindase activities were statistically analyzed using Kruskal-Wallis test by ranks. The different letters indicate a significant difference $(P$ value <0.05). The error bars represent standard deviation.

Figure S2. Experimental design to measure the potential EM fungal respiration and ${ }^{13} \mathrm{CO}_{2}$ transfer in a control Magenta box. A. Magenta box with a non-mycorrhized seedling (Scots pine), without $P$. placenta necromass. B. Magenta box with a mycorrhized seedling, with P. placenta labelled necromass. Boxes were connected with a flexible and hermetic tube.

Figure S3. A. Image of the mycorrhizal association between Pinus sylvestris and Paxillus involutus in the Magenta boxes. B. Detail of an ectomycorrhizal root tip. 